\title{
Enhancing Efficiency of Baltic Retail Contact Centers
}

\section{Iveta Linina}

Business University Turiba

\section{Velga Vevere}

The University College of Economics and Culture

\section{Rosita Zvirgzdina}

Business University Turiba

$\Gamma$ Crossef http://dx.doi.org/10.5755/j01.eis.0.12.21874

Private consumption is one of the main cornerstones of economic growth in any country. Retail sales also play an important role in today's society and in the national economy as it introduces and develops new technologies in customer service, provides jobs and increases the welfare of society. Adapting to customer needs and requirements gives the company, on the one hand, the opportunity for further development and increase of competitiveness, but, on the other hand, it necessitates organizing customer service and improving the use of existing resources for the management of the customer service process. In order to identify the factors for effective management of communication with customers, the authors aim to study the factors characterizing and influencing the effectiveness of retail contact centers. To accomplish that, the authors of the article with a monographic or descriptive method investigate the theoretical basis of efficiency management, analyze the trends of the retail sector in Latvia and investigate the application of the principles of Queueing theory to ensure the efficiency of customer service of Latvian retail companies. This research will give companies an insight into the theoretical and real factors of the queueing theory. In the end of the study, the authors conclude that by exploring the factors of the queueing theory, the company can manage this process and maybe it is one of the tools for competitiveness.

KEYWORDS: retail trade, effectiveness, efficiency, queuing theory, contact center.

Private consumption plays an important role in any national economy. Retailers implement and develop new technologies, provide jobs, and enhances the welfare of the society. At the same time, advanced technology, skilled personnel and state-of-the-art equipment alone cannot guarantee the competitiveness of a retail company, increase of the value of a private company. In the long run, the priority of each retail business should be the transition to a cost-effective management system and a resource-efficient economy. For the sake of competitiveness and the attainment of goals, the retail company can use efficiency principles in all operational processes. (Sen, 1993)

Any business is based on satisfying the wishes and needs of the customer. Orientation towards the buyer and his needs, effective communication is a factor in the customer-oriented approach

\section{EIS $12 / 2018$}

Enhancing Efficiency of Baltic Retail Contact Centers

Submitted 04/2018

Accepted for publication 10/2018

\section{Abstract}

\section{Introduction}

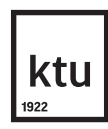

European Integration Studies No. 12 / 2018 pp. 129-138 DOI 10.5755/j01.eis.0.12.21874 
to business management. According to the existing research, to attract a new buyer is $5-10$ times more expensive than selling to an existing buyer, and the existing buyers spend $67 \%$ more money than the new buyers (Anderson et al., 2007). Hence, one of the main tasks of the retail specialists is devising the effective communication system that would prompt customers to repeat purchase and maintain further relations with enterprise. To ensure that in the sphere of the retail trade the significant role is played by the call centers. The current article researches possibilities and advantages of the effective use the call centers. The aim of the research is to evaluate the effective principles of call centers in retail trade, as a tool for increasing customer satisfaction. To attain this aim the following tasks were put forward:

1. To research the theoretical framework of process effectiveness

2. To characterize the sphere of retail trade and conditions for organizing call centers

3. To establish the level of call center effectiveness and their potential in the retail trade enterprises.

The research question of the current research: What factors do ensure effective communication with customers in retailing?

In order to determine the contact center development tendencies work out suggestions for enhancing THE effectiveness, 257 retail enterprise customers from the Baltic countries (Latvia, Estonia and Lithuania) were surveyed. Due to the specific aspects of communication between call centers and customers this particular research had the following limitations: communication with customers is researched only through the call centers, as well as their demographic characteristics were not taken into account. The research period was 1, January - 1, April, 2018. The following research methods were used: the monographic or descriptive and the logical-constructive to set the empirical findings against the theoretical background; the customer survey to determine the effectiveness of communication channels; the graphical method for visualization and analysis of data. The theoretical and methodological framework of the current article consists of publications by P. Drucker, V. Neufeldt, A.N. Spark, A.K. Erlang and others, as well as theoretical and practical reflections upon activities of retail enterprises, as well as materials of scientific conferences and seminars.

At first, it would be necessary to turn to the concept of effectivity. According to P. Drucker, effectivity implies that the balance of all production factors provides maximum return with the minimum effort. Profit is the company's effective performance in terms of marketing, innovation and efficiency. In the words of P. Drucker, if the productivity means "to do things correctly", then the effectiveness - "to do correct things". He also developed the model of effective management. This model rests on five principles that are to be observed by the manager to ensure his efficiency: 1) to plan ones time; 2 ) to orientate oneself towards success and final result; 3 ) to develop strengths of oneself and employees; 4) to determine enterprise priorities and to concentrate upon main spheres of activity for getting better results; 5 ) to make effective decisions. (Drucker, 1954, Drucker, 1994)

It is obvious that conceptions of the effectiveness itself are rather diverse, each author offers a different interpretation. (Emerson, 1917; Drucker, 1954; Коуз, 2015) Majority of the authors associate it with the rational use of resources, still there are alternative opinions as well. Upon analysis of them we can conclude that there are differences in explanation and interpretation of the concept itself. Thus, for example, there is a non-discriminatory view of it, the one that effectiveness means the same as efficiency, while other researchers believe that effectiveness can be defined as appropriation of internal resources, hence - efficiency. Overall, it is admitted that the 
concept of effectiveness rests upon three elements: investments, short-term performance and long-term performance. The concept of efficiency refers to both the consumption and the quality of the specific results achieved.

Economic effectiveness (efficiency) determines the use of resources with minimum losses, while functional effectiveness determines the achievement of higher goals. Based on the scientific publications, the authors propose such definitions of effectiveness:

1 Efficiency, effectiveness describes the achieved performance against the resources used to achieve a certain result;

Economic effectiveness (efficiency describes the way how a system or its components achieve the desired performance compared to the resource consumption, providing maximum return on resources and their use with minimal losses;

3 Functional effectiveness describes how any system or its components achieves the desired performance compared to resource consumption, providing maximum return on resources and their use with minimal losses. (Kotāne, 2014)

- Another research on effectiveness was carried out at the Debrecen University. It was related to explanation of the concept in different dictionaries:

_ Efficiency - achieving the desired result with minimal effort, expenses and losses; (Neufeldt, Sparks, 1995)

_ Efficiency - achieving the desired results with as little investment as possible or maximizing the results with existing resources; (Black et al., 2002)

Efficiency - functional, technical efficiency; the manufacturer's ability to produce a maximum output with acceptable quality with minimal investment; economic efficiency: the enterprise's ability to produce and distribute its products at minimum prices. (Black et al., 2009)

_ Besides that, the definition of productivity is being mentioned, since according to the authors, it exhibits similar features to the one of efficiency. Productivity is the result of an organization or economy per unit (work, material resources, capital, etc.). (Black et. al., 2002).

The authors of the current study agree that the concept of effectiveness is very broad and not clear. It can be noted that some authors define effectiveness only in relation to the efficient use of resources, but some distinguish between economic and functional efficiency, which allows to assess separately both the use of resources, the achievement of objectives and pricing principles. This second approach seems to be more adequate as the company's operation is a complex process that includes resource planning, setting short-term and long-term goals for enterprise development and innovation, and employee motivation to improve performance, as well as pricing procedures. The activity of an enterprise cannot be assessed solely on the basis of resource use, since this assessment will not be complete and will not reflect the existing situation in the full.

Therefore, the authors believe that the definition should be split in two - economic and functional effectiveness, which more fully reflects its essence. So, the economic effectiveness is ability of an enterprise to produce a good quality product or provide a quality service using as little labor, raw material or capital resources as possible. In turn, the functional effectiveness is ability of an enterprise to achieve results that meet the objectives set. Summarizing these definitions, it can be concluded that efficiency (effectiveness) is ability of an enterprise to produce a quality product or to provide a quality service with the least investment possible and to achieve the objectives.

Several theories of efficiency are considered in the scientific literature, such as the ones of Constraints, Queueing, LEAN, Six Sigma, Total Quality Management, etc. The queueing theory is 
one of the methods of mathematical modeling, which aims to provide the theoretical basis for modeling and efficient operation of the queuing systems. The use of the theory in practice allows the company to avoid situations where the customer is forced to wait for a long time or eventually to give up the service because the company has poorly the organized customer flow. This theory employs mathematical statistics and probability theory. The founder of the queueing theory is Danish scientist A.K. Erlang As a telephone company employee in the beginning of the 20th century he published his work "Probability Theory and Telephone Conversation," where he addressed the customer service problems associated with the abandonment of services by the means of the queueing theory.

There are mass servicing systems with and without standby time. In the latter case, the customer leaves the system without receiving the service, because his application is not processed due to the system congestion. Such systems need to take into account losses. Systems that do not want to lose customers, can make use of this theory can be useful in order to organize customer flow more effectively and ensure the processing of all applications.

The queueing theory is suitable for mass-servicing systems with a large flow of customers and limited possibilities for processing all applications. Each mass service system has a number of service channels. These channels are unevenly occupied and their level of occupancy cannot be predicted. When service channels are busy, they cannot serve future customers until they are free, so a queue is forming. The subject of the queueing theory is the determination of dependencies between the flow of the application, the productivity of the individual channels and efficient service with the aim of finding the best way to manage this process. The main task of the theory is to study the functioning of the service system. This includes the economic aspect of defining a type of the system, which will minimize the total costs associated with the loss of time and other resources. (Кошуняева, Патронова, 2013; Sztrik, 2012)

There are certain elements in each mass servicing system:

_ Flow of incoming applications

- Queue

_ Service channels

_ Outbound flow of serviced applications

To describe the effectiveness of the functioning of the service system, three group indicators can be used:

\section{Service system performance}

indicators:

absolute throughput capacity of the system - the average number of applications that a system can handle in a time unit;

- relative throughput capacity of the system - the ratio between the average number of applications that can be served by the system in the time unit and the number of the incoming applications;

_ average system load time;

_ system utilization rate - average time when the system is loaded.

2 Application servicing quality

indicators:

- average waiting time in the queue

- average time for the application to be in the system; 
- probability that the application will be rejected without waiting in the queue;

_ probability that the repeatedly incoming application will be taken out of the queue;

- the procedure for determining waiting time;

_ procedure for determining the time in the application system;

_ average number of applications in the queue;

_ average number of applications in the system.

3 "System-Client" relationship efficiency

indicators ("Client" - the sum of all applications):

_ Uniform flow - if all applications are equal, if only the time of receipt of the application is taken into account without specifying the details of the application.

- Flow without the following action - the number of events at any time period does not depend on the number of events in any other time period not related to the current one.

- Stationary flow - the probability of events over a period of time does not depend on time, but depends only on the length of the area.

- Simple flow - the uniform stationary flow without the following action is a simple, or Poisson flow. In practice, simple flows are rarely found, but simulated flows can be assumed to be simple. This facilitates calculations and allows modeling the situation in a simplified manner.

When analyzing the service system, it is necessary to determine first what type it belongs to. Often it consists of different elements and each of them has its own application servicing procedure. There are single-channel systems, multichannel, systems with refusals, standby times, with and without priorities. Signatures for retail call centers consist of multiple multichannel systems with different throughput capabilitie-s, either with standby time or with refusals. (Кошуняева, Патронова, 2013)

In the retail sector, where direct contact between the company's staff and the buyer is taking place, personal service is traditionally very important when vendors or other sales staff help to select a product, provide advice and other services. At the same time, there is communication a dialogue between the retailer's staff and customers that significantly affects their behavior by choosing where to make purchases.

Personal service has not lost its momentum nowadays, but at the same time, changes in buying patterns must also be taken into account. In the context of the development of information technology and internet, customers increasingly want to make communication (including dialogue) and purchase goods via electronic means. Consequently, contacts with the retail business staff take place not only directly at the point of sale but also remotely. Due to the changing characteristics of the target audience, customer service methods and principles must be changed as well. (Ronen et al., 2006).

One of the existing potential customer service tools based on the advanced information technology is the call center. In the current situation, the retail centers of the Baltic States are mainly focused on processing incoming and outgoing calls, and thus effectively fulfill the functions of the secretariat. Information technologies are used mainly to meet technical needs that are not related to creating interaction with buyers. As a result, retailers face the following problems with communication with customers:

_ phones are busy;

_ calls are directed to inappropriate employees;

_ customers have to wait long time for the answer; 
_ operators can't find the necessary information:

_ customers are not satisfied with the answer;

_ customers receive impolite answer;

_ information from buyers is processed for a relatively long time or remains unanswered;

- there is no coordination among information channels - phones, internet sites, etc.

To solve such problems, it is necessary to apply the effective management of these processes, which can be ensured by the application of the queuing theory. It involves the centralized processing and servicing the incoming and outgoing calls through various interactive channels. These interactions are implemented by the professional operators working in a technically and technologically equipped contact centers. Each operator has access to a marketing database that helps to find or enter the necessary information about the buyers with whom they are communicating at the moment. The basis for it is the management of interactive channels - digital telephony, processing subsystem for messages in the homepage and e-mail, the SMS processing subsystem. It is precisely functionality of this block that determines the amount, structure and quality of information that will be sent to the operator at the work place. On the other hand, the operator, through the marketing database, ensures the connection of the information provided or requested by the buyer with information that satisfies him by content and perception. Information regarding customer, his values (including purchased items), complaints, etc. in the marketing database is retrieved from loyalty cards, receipts, filled in questionnaires, previous calls, online purchases, social networks, and more.

In order to utilize marketing data base information it is necessary to apply the computer telephony integration that will make it possible:

_ to distribute calls automatically;

_ to determine caller's phone numbers automatically;

_ to identify customer and find an appropriate form of communication.

The operator then finds out what the problem is and looks for a solution in the marketing database. Without a standard solution to the problem, it is automatically sent to the responsible employee of the service department, of the according department, of the product category or other. Depending on the content of the problem and the solution, the system formulates the task for the operator - to report to the customer what exactly a retail company employee does to solve the problem. This demonstrates that the work of the retail company is oriented towards meeting the needs of the buyers and building relationships with them. The contact center can also be used for communication with prospective buyers, providing them with information about goods, services, events, etc.

There are several advantages of using the contact center (see Table 1). At the same time, it should be noted that the preparation and implementation of the contact center activities requires some financial investment, such as equipment, software, personnel, training, etc. Such costs can mainly be afforded by the relatively large (by turnover and profit) retail companies. For others, it is useful to use the services of a professional contact center and pay fees. In any case, efforts should be made to calculate the effectiveness of use. Collaboration with professional centers also raises certain problems because they work with their clients and in essence they cannot (or do not want to) go deep into each company's problems. A formal attitude can lead to formal results that do not contribute to the increased customer loyalty.

The authors on the basis of special literature and clarification of the needs of cooperation partners adapted the contact center model for the retail trade enterprises taking into account their operational characteristics (see Figure 1). (Черкашин, 2014) 


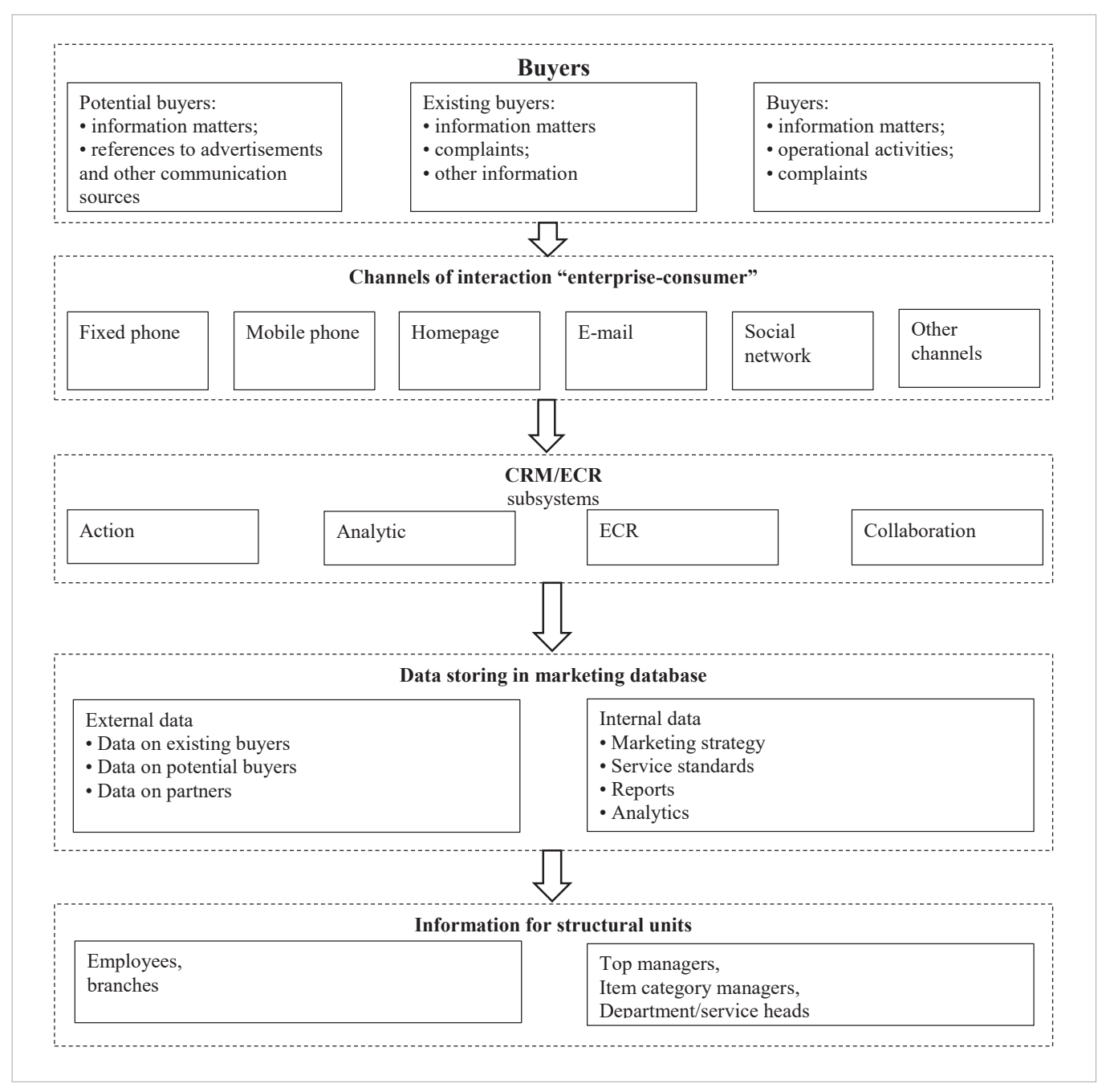

It is very important to understand the operation of these contact points particularly from the point of view of customers. Based on the literature, the authors of the study developed the list of advantages of using the contact center for retail companies (see Table 1). (Черкашин, 2014)

\begin{tabular}{l|l|l}
\hline \multicolumn{1}{c|}{ Criteria } & \multicolumn{1}{c}{ Retaining existing customers } & \multicolumn{1}{c}{ Attracting new customers } \\
\hline Indicators & $\begin{array}{l}\text { Increase of repeat purchase ratio } \\
\text { Increase of customer loyalty ratiol } \\
\text { increase of customer satisfaction level }\end{array}$ & $\begin{array}{l}\text { Reducing costs per customer } \\
\text { Optimization of marketing budget }\end{array}$ \\
\hline Spheres of application & $\begin{array}{l}\text { Customer support } \\
\text { Establishing of “hot line" } \\
\text { Claim/complaint management } \\
\text { Research of customer needs } \\
\text { Organization of internet and phone sales }\end{array}$ & $\begin{array}{l}\text { Optimization of communication } \\
\text { channels } \\
\text { Organization of internet and } \\
\text { phone sales } \\
\text { Management of category of goods } \\
\text { Market research }\end{array}$ \\
\hline Means of reaching the target & $\begin{array}{l}\text { Effective delegating of tasks } \\
\text { Development of integrated communications }\end{array}$ \\
\hline
\end{tabular}

Source: Authors' compilation according to Черкашин, 2014. Linina et al., 2017, Linina, 2017
Figure 1

The scheme of contact center performance for retail trade enterprises (Authors' compilation according to Черкашин, 2014)

\section{Table 1}

Advantages of contact centers in retail trade enterprises 
By using principles of the queuing theory in retail companies, by establishment of a successful contact center and integration of the contact center function and marketing database it is possible to significantly increase the customer satisfaction and build relationships that, in its turn, enhances customer loyalty and creates the competitive advantage in the market.

Research results

Table 2

Evaluation of communication between retailers and customers
During the time period from January 2018 to March 2018, the authors have conducted a customer survey. The survey questions were focused on effective retail communication with customers, in order to determine the use of the principles of lean management concept. The survey sample: 257 customers of the Baltic retail enterprises selected randomly in the database available to authors. All data obtained from the survey were found to be usable for the study. Data were processed by the SPSS program. Due to the specific aspects of communication between call centers and customers this particular research had the following limitations: communication with customers was researched only through the call centers, as well as their demographic characteristics were not taken into account.

The research question of the current research: What factors do ensure effective communication with customers in retailing?

The survey questions were divided into two blocks - the first one concerning the non-sales communication, while the second one - related to the problem solving. Within each block the respondents could evaluate several elements according to the Likert scale in the 10-point system, where 1 means very bad, and 10 - outstanding. The results of the survey are presented by authors as a summary of the two main question blocks (see Table 2).

\begin{tabular}{|c|c|c|c|c|c|c|c|c|c|}
\hline $\begin{array}{c}\text { Evaluation of communication } \\
\text { between retailers and } \\
\text { customers }\end{array}$ & $\begin{array}{l}\stackrel{c}{\mathbb{N}} \\
\stackrel{\mathbb{d}}{\Sigma}\end{array}$ & 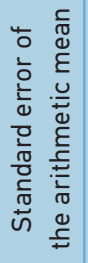 & 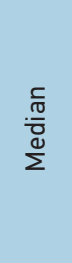 & $\begin{array}{l}\frac{0}{0} \\
\frac{0}{\Sigma}\end{array}$ & 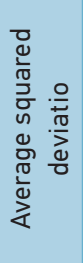 & $\begin{array}{l}\frac{.0}{0} \\
\frac{0}{0} \\
\frac{0}{0} \\
\frac{.0}{0}\end{array}$ &  & 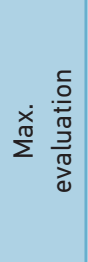 & 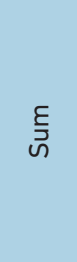 \\
\hline Evaluation of non-sales communication & 5.78 & 0.78 & 5.00 & 4.00 & 2.35 & 5.5 & 4.89 & 9.00 & 48.00 \\
\hline Evaluation of problem solving & 3.27 & 0.70 & 3.00 & 2.00 & 2.11 & 4.44 & 7.27 & 8.00 & 29.00 \\
\hline
\end{tabular}

Source: Authors

As can be seen in the block of questions on the non-sales communication, the average arithmetic mean is slightly above the average $\left(X t^{\prime}=5.78\right.$; $M e=5.00$; $\left.M o=4.00\right)$, which could not be regarded as positive for business communication with customers. The question block for evaluating company's problems and issue solving the indicator is very low $\left(X^{-}=3.27\right.$; Me $=3.00$; Mo $=2.00$ ), which demonstrates that there are huge problems in retail companies in this field. In order to evaluate the real performance of the company in the field of communication, the authors of the study consider the concept of productivity and its significance. Productivity in economics is a concept that describes the relationship between the product (service) delivered and the resources used for this purpose. In the economic theory, various mathematical models are used, by which economic development tendencies are being analyzed. One of the historically first was the Cobb-Douglas two-factor model, where factors of production are work and capital. The ability of these two factors to promote economic growth is also characterized by productivity in microeconomics (Ivanovs et al., 1981). Productivity can be measured by comparing costs with revenue. In the case of effective communication, productivity can be measured by customer satisfaction and loyalty. 
The use of the queueing theory in the retail business call centers is an effective way of communicating with customers in the first place. The effective communication is the key to the relationship with customers building that, in its turn, ensures the customer satisfaction and loyalty. The satisfied and loyal customer increases the competitiveness of the retail business.

Summarizing the results of the research, several conclusions and recommendations can be made:

1 The factors that ensure effective communication with customers in the call centers in retailing in the Baltic countries are non-sales communication (working hours, parking possibilities, availability of additional service, etc.) and problem solving. As can be seen in the block of questions on the non-sales communication, the average arithmetic mean is slightly above the average, which could not be regarded as positive for business communication with customers. The question block for evaluating company's problems and issue solving the indicator is very low, which demonstrates that there are huge problems in retail companies in this field.

2 There are several theories and methods of increasing the efficiency of an enterprise. Taking into account the structure and work of the company, it was concluded that the best results will be achieved by the use of criteria and tools of the queuing theory, the theory of constraints and the lean management theory.

3 By the successful contact center performance and integration of contact center and market3 ing database functions it is possible to gain such advantages:

_ to attract and retain consumers with the help of new information technologies;

_ to reduce the cost of the contact center, as the automation of responses to repeated questions makes it possible to reduce the number of operators;

_ to increase the productivity of operators thanks to reduction of the time of each call and increase of the number of incoming calls;

_ to give each customer more time while increasing their number;

_ to obtain new competitive advantages.

4

Retail call centers need to implement a call waiting feature with an answering machine so

that incoming calls are not lost due to the congestion of phone lines.

5 During rush hours responsibilities of employees must be shared so that one administrator is always available to handle incoming calls.

Timely correspondence processing should be ensured so as not to lose customers who chose communicate via internet.
Anderson, J. L., Jolly, L. D., Fairhurst, A. E. (2007). Customer relationship management in retailing: a content analysis of retail trade journals, Journal of Retailing and Consumers services, 14(6), 394-399.

Black, J., Hashimzade, N., Myles, G. (2002). A Dictionary of Economics. Second Edition (p. 28). Oxford: Oxford University Press.

Black, J., Hashimzade, N., Myles, G. (2009) A Dictionary of Economics. Third Edition (p. 528). Oxford University Press.
Drucker, P.F. (1954). The practice of management (p. 404). New York : Harper \& Row.

Drucker, P. F. (1994). Adventures of a Bystander (p. 344). Piscataway, NJ: Transaction Publishers.

Emerson, H. (1917). The twelve principles of efficiency. 5th Edition (p. 423). New York : Engineering Magazine.

Erlang A.K. (1909). The Theory of Probabilities and Telephone Conversations, Nyt Tidsskrift for Matematik, B 20, 33-39.
Conclusions and recommendations 
Ivanovs, A.u.c. (1981). Sociolog̉isko pētījumu metodolog̉ija, metodika un tehnika (242 lpp.). Rīga: Zvaigzne.

Kotāne, I. (2014). Komercdarbības efektivitātes jedziens un tā interpretācija, Sociālo zinātṇu žurnāls, 1(6), 107.-111.

Linina, I., Vevere, V., Zvirgzdina, R. (2017). Evaluation of customer relationship management formation in the retail trade enterprises in the Baltic countries, Globalization And Its Socio-Economic Consequences. Proceedings. Zilina: University of Zilina, 1307-1316.

Liniṇa, I. (2017). Attiecību ar patērētājiem vadības sistēmas ieviešana un lietošana Baltijas valstu mazumtirdzniecības uzṇēmumos. Promocijas darbs (185 lpp.). Rīga: Turība.

Neufeldt, V., Sparks, A.N. (1995). Webster's New World Dictionary (p. 694). New York: Pocket Books.
Ronen, B., Pliskin, J. S., Pass, S. (2006). Focused Operation Management for Health Service Organizations (p. 354). San Francisco: Jossey-Bass.

Sen, A. (1993). Markets and freedom: Achievements and limitations of the market mechanism in promoting individual freedoms, Oxford Economic Papers, 45 (4), 520-522.

Sztrik, J. (2012). Basic Queueing Theory (p. 193). Debrecen: University of Debrecen.

Кошуняева, Н.В., Патронова, Н.Н. (2013). Теория массового обслуживания (109с.). Архангельск: САФУ имени М.В. Ломоносова.

Коуз, Р. (2015). Очерки об экономической науке и экономистах (288 с.). СПб: Факультет свободных искусств и наук СПбГУ.

Черкашин, П. (2014). Стратегия управления взаимоотношениями с клиентами (СРМ) (375 с.). М.: Интернет- университет информационны технологий.

\section{About the} authors

\section{LININA IVETA}

Dr. oec.,

Business University Turiba

Fields of research interests

Retail trade, marketing, marketing communications, sales management

\section{Address}

Graudu 68, Riga LV 1058, Latvia,

Tel. +37126306922

E-mail: iveta.linina@turiba.lv

\section{ZVIRGZDINA ROSITA}

Dr. oec.

Business University Turiba

Fields of research interests

Economics, performance

efficiency, strategic management

Address

Graudu 68, Riga LV 1058, Latvia,

Tel. +371 26408253

E-mail:velga.vevere@gmail.com

\section{VEVERE VELGA}

\section{Dr. phil}

The University College of Economics and Culture

\section{Fields of research interests}

Business ethics, management, corporate social responsibility, corporate governance

\section{Address}

Lomonosova 1/5, Riga LV 1019,Latvia, Tel. +37126463584

E-mail: rosita@turiba.lv 